九州大学学術情報リポジトリ

Kyushu University Institutional Repository

Field Evaluation of

Cartap, Cyromazine, Permethrin and Phenthoate for Control of the Stone Leek Leafminer Liriomyza chinensis (Diptera: Agromyzidae)

Tran, Dang Hoa

Graduate School of Bioresource and Bioenvironmental Science, Kyushu University

Le, Van Hai

College of Agriculture and Forestry, Hue University

Luong, Thi Bich Phuong

Faculty of Agronomy, College of Agriculture and Forestry, Hue University

Takagi, Masami

Faculty of Agriculture, Kyushu University

https://doi.org/10.5109/9240

出版情報：九州大学大学院農学研究院紀要. 51 (2)，pp.265-268，2006-10-27. Faculty of Agriculture, Kyushu University

バージョン：

権利関係 : 


\title{
Field Evaluation of Cartap, Cyromazine, Permethrin and Phenthoate for Control of the Stone Leek Leafminer Liriomyza chinensis (Diptera: Agromyzidae)
}

\author{
Dang Hoa TRAN ${ }^{1}$, Van Hai LE ${ }^{2}$, Thi Bich Phuong LUONG ${ }^{3}$ \\ and Masami TAKAGI*
}

\author{
Laboratory of Insect Natural Enemies, Division of Biological Control, Department of Applied Genetics \\ and Pest Management, Faculty of Agriculture, Kyushu University, \\ Fukuoka 812-8581, Japan \\ (Received June 27, 2006 and accepted July 24, 2006)
}

\begin{abstract}
The stone leek leafminer, Liriomyza chinensis (Kato), has become a serious pest on onioncrops in the whole Vietnam, and it is treated by a wide range of conventional insecticides. Growers apply insecticides early after a few mines on several leaves have been seen, and repeated applications are usually made. Field trial was conducted to evaluate the effects of a single application of four currently and potentially used insecticides on $L$. chinensis. These insecticides were applied at recommended field rates. Leaf samples were used to monitor larval population, and yellow sticky traps were used to monitor adult population. Cyromazine was effective on the larvae, but no effective on the adults. Cartap, permethrin and phenthoate were not or less effective on neither larvae nor adults of the leafminer. These results suggest that cyromazine application provide one potential component of an effective L. chinensis control strategy for Vietnamese onion farmers.
\end{abstract}

\section{INTRODUCTION}

The stone leek leafminer, Liriomyza chinensis (Kato), has occurred and become a serious pest on Allium spp. in China, Japan, Malaysia, Singapore, Thailand (Spencer, 1973, 1990, Chen et al., 2003), Korea (Hwang and Moon, 1995), and Taiwan (Shiao, 2004). Recently, outbreak of the leafminer has been found in onion crops across Vietnam (Andersen et al., 2002, Tran and Takagi, 2005), especially Hue region where Japanese bunching onion (Allium fistulosum L.) are mainly produced. Several hectares are planted annually for year-round production.

Liriomyza chinensis is specialist pest on Allium spp. Damage caused by L. chinensis to onion plants is very similar to other Liriomyza species: larvae mine and feed within the leaves, and females produce punctures on the leaves with their ovipositor for the adult's feed and oviposition. Because the quality of onion leave production is directly affected by the damage of the leafminer with its rapid increase and spread in the fields, growers in Vietnam have frequently applied large quantities of broad-spectrum insecticides (Tran and Takagi, 2005). Growers apply insecticides early when they see a few mines on several leaves, and may continue to treat once or twice a week until the end of planting season. Frequent applications of broad-spectrum insecticides, however, adversely affect parasitoid abundance in the

\footnotetext{
1 Laboratory of Insect Natural Enemies, Division of Biological Control, Department of Applied Genetics and Pest Management, Graduate School of Bioresource and Bioenvironmental Sciences, Kyushu University, Japan

2 Department of Plant Protection, Faculty of Agronomy, College of Agriculture and Forestry, Hue University, Vietnam

${ }^{3}$ BVTV35, Faculty of Agronomy, College of Agriculture and Forestry, Hue University, Vietnam

* Corresponding author (E-mail: mtakagi@grt.kyushu-u.ac.jp)
}

vegetable agro-ecosystem (Johnson et al., 1980; Saito et al., 1996; Thang, 1999), can promote the development of pesticide resistance within fly populations (Keil et $\mathrm{al}$., 1985; Johansen et al., 2003) and frequently lead to an increase in leafminer density (Oatman and Kennedy, 1976; Murphy and LaSalle, 1999).

Since laboratory tests on Japanese L. chinensis indicated that cartap, cyromazine, permethrin and phenthoate could be effective in controlling the leafminer (Tran and Takagi, 2005), the objective of this study was to observe the effects of a single field application of these insecticides on L. chinensis in Hue City, Vietnam. We also consider why potential insecticide application in the fields was ineffective in controlling $L$. chinensis.

\section{MATERIALS AND METHODS}

\section{Field preparation and insect monitoring}

Field experiment was conducted from March to May 2005 at commercial onion fields in Thuan Loc ward, Hue City, Vietnam. The Japanese bunching onion ( $A$. fistulosum) variety was used. Plots consisted of $10 \mathrm{~m}^{2}$ arranged in randomized complete blocks designs with four replications. The commercial formulations of four insecticides, cartap (Padan 95 SP), cyromazine (Trigard $75 \mathrm{WP}$ ), permethrin (Peran 10 EC) and phenthoate (Elsan 50 EC) were diluted with pure water and applied at field rates based on the recommended label dilutions (Table 1). These compounds were selected on the basis of their high efficacy on either larvae or adult bioassays of L. chinensis in the laboratory (Tran and Takagi, 2005), and their current and potential use for the management of leafminers affecting vegetable crops in Vietnam. Leafminer-infested plants were sprayed by using power-pack hand sprayers. As a control, pure water was applied in the same as insecticide above. The number of mines and live larvae of the leafminer was 
counted on 15 infected leaves of each plot in 1 day before treatment (DBT), and 1, 3, and 7 days after treatment (DAT).

Since yellow sticky board was the most effective in trap capture Liriomyza flies (Chaves and Raman, 1987), we used the trap to determine the impact of insecticides on adults of $L$. chinensis. One yellow sticky board $(10 \mathrm{~cm} \times 20 \mathrm{~cm})$ was placed at $60 \mathrm{~cm}$ height using a wooden stake in the middle of each plot at 2DBT. The sticky paper was replaced at 0,2, 4DAT. The trap counts of number of $L$. chinensis adults were made at $48 \mathrm{~h}$ after replacing new sticky paper (0 DBT, 2 , 4 and 6 DAT).

\section{Data analysis}

To examine the effects of insecticide treatment on the number of mine, live larva and adult mean values were computed for each replication plot and one-way ANOVA were undertaken. Means were separated by Tukey-Kramer test (SAS Institute, 1998)

\section{RESULTS}

There was no significant difference in mean number of mines made by $L$. chinensis among the treatments $(P>0.05)$ (Table 1$)$. Three days after treatment, the mean number of live larvae was significant difference among the treatments ( $\mathrm{df}=3,16 ; F=1.62 ; P<0.05)$ (Table 2). The number of live larvae for cyromazine was significantly smaller than that for the control $(P<0.05)$. Seven days after treatment, the mean number of live larvae was also significant difference among the treatments (df $=3,16 ; F=2.05 ; P<0.05$ ) (Table 2). The number of live larvae for cyromazine was significantly smaller than that for the control $(P<0.05)$. There was no significant difference in mean number of adults among the treatments $(P>0.05)$ (Table 3$)$.

\section{DISCUSSION}

In Vietnam, cyromazine has been currently registered for leafminer management, but is still not commonly used (Johansen et al., 2003; Tran and Takagi, 2005). The present study has shown that seven days after application of cyromazine, most of L. chinensis larvae present in onion leaves were killed (Table 2). This result is consistent with laboratory tests using Japanese L. chinensis indicating that cyromazine is highly effective on $L$. chinensis larvae (Tran and Takagi, 2005). Since the translaminar effect of cyromazine enables effective penetration of the leaves that affects leafminer larvae (Weintraub, 2001), application of cyromazine has the potential to provide control of other leafminers such as L. trifolii (Burgess), L.

Table 1. Effect of insecticides on the number of mines damaged by L. chinensis on one infested onion leaf (Mean \pm SE)

\begin{tabular}{|c|c|c|c|c|c|}
\hline Treatment & Dilution & 1DBT* & 1DAT* & 3DAT & 7DAT \\
\hline Cyromazine & $1000 x$ & $8.8 \pm 1.6 \mathrm{a}$ & $8.1 \pm 1.1 \mathrm{a}$ & $5.9 \pm 0.6 \mathrm{a}$ & $10.9 \pm 1.3 \mathrm{a}$ \\
\hline Permethrin & $2000 \times$ & $9 \pm 1.9 \mathrm{a}$ & $6.8 \pm 1.3 \mathrm{a}$ & $6.9 \pm 0.8 \mathrm{a}$ & $9.8 \pm 0.9 \mathrm{a}$ \\
\hline Phenthoate & $1000 \times$ & $10.7 \pm 1.3 \mathrm{a}$ & $8.2 \pm 0.5 \mathrm{a}$ & $7.5 \pm 0.2 \mathrm{a}$ & $12 \pm 1.3 \mathrm{a}$ \\
\hline Cartap & $1500 \times$ & $8.7 \pm 0.9 \mathrm{a}$ & $7.3 \pm 1.1 \mathrm{a}$ & $7.1 \pm 1.1 \mathrm{a}$ & $10.7 \pm 1.3 \mathrm{a}$ \\
\hline Water & - & $8.5 \pm 0.4 a$ & $4.9 \pm 1.6 \mathrm{a}$ & $6.3 \pm 0.5 \mathrm{a}$ & $10.8 \pm 1.3 \mathrm{a}$ \\
\hline
\end{tabular}

Means with the same letters within the same column are not significantly different by one way ANOVA, P $<0.05$.

*DBT (days before treatment); DAT (days after treatment)

Table 2. Effect of insecticides on the number of live larvae L. chinensis in one infested onion leaf (Mean \pm SE)

\begin{tabular}{|c|c|c|c|c|}
\hline Treatment & 1DBT* & 1DAT** & 3DAT & $7 \mathrm{DAT}$ \\
\hline Cyromazine & $5.6 \pm 0.9 \mathrm{a}$ & $4.5 \pm 1.3 \mathrm{a}$ & $4 \pm 1 \mathrm{a}$ & $0.3 \pm 0.5 \mathrm{a}$ \\
\hline Permethrin & $4.5 \pm 1.3 \mathrm{a}$ & $3.5 \pm 1.9 \mathrm{a}$ & $5.5 \pm 0.6 \mathrm{ab}$ & $2 \pm 0.4 \mathrm{~b}$ \\
\hline Phenthoate & $3 \pm 1.4 \mathrm{a}$ & $3.3 \pm 1.4 \mathrm{a}$ & $4.3 \pm 1.5 \mathrm{ab}$ & $1.3 \pm 0.5 b$ \\
\hline Cartap & $3.3 \pm 1.4 \mathrm{a}$ & $3.3 \pm 0.9 \mathrm{a}$ & $4.3 \pm 0.5 \mathrm{ab}$ & $1 \pm 0.6 \mathrm{~b}$ \\
\hline Water & $4 \pm 2.2 \mathrm{a}$ & $4 \pm 1.4 \mathrm{a}$ & $7.8 \pm 1.9 \mathrm{~b}$ & $2.3 \pm 0.3 b$ \\
\hline
\end{tabular}

Means with the same letters within the same column are not significantly different by Tukey-Kramer test after one way ANOVA, P $<0.05$. *DBT (days before treatment); DAT (days after treatment)

Table 3. Effect of insecticides on the number of adult L. chinensis captured by yellow sticky trap (Mean \pm SE)

\begin{tabular}{|c|c|c|c|c|}
\hline Treatment & ODBT* & $2 \mathrm{DAT}^{*}$ & $4 \mathrm{DAT}$ & $6 \mathrm{DAT}$ \\
\hline Cyromazine & $1.9 \pm 0.9 \mathrm{a}$ & $1.5 \pm 0.9 \mathrm{a}$ & $2.8 \pm 0.5 \mathrm{a}$ & $19.3 \pm 0.5 \mathrm{a}$ \\
\hline Permethrin & $3.9 \pm 1.9 \mathrm{a}$ & $2.3 \pm 0.6 \mathrm{a}$ & $3.5 \pm 0.9 \mathrm{a}$ & $22 \pm 2.4 \mathrm{a}$ \\
\hline Phenthoate & $3.1 \pm 1.6 \mathrm{a}$ & $1.8 \pm 0.9 \mathrm{a}$ & $2.8 \pm 0.9 \mathrm{a}$ & $18.8 \pm 5.5 \mathrm{a}$ \\
\hline Cartap & $4 \pm 1.1 \mathrm{a}$ & $3.3 \pm 0.5 \mathrm{a}$ & $3.3 \pm 0.8 \mathrm{a}$ & $18.2 \pm 2.1 \mathrm{a}$ \\
\hline Water & $3.3 \pm 0.5 \mathrm{a}$ & $2.3 \pm 0.3 \mathrm{a}$ & $4 \pm 1.1 \mathrm{a}$ & $20 \pm 1.9 \mathrm{a}$ \\
\hline
\end{tabular}

Means with the same letters within the same column are not significantly different by one way ANOVA, P $<0.5$

*DBT (days before treatment); DAT (days after treatment) 
huidobrensis (Blanchard), L. sativae Blanchard, L. bryoniae (Kaltenbach) and Chromatomya horticola (Goureau) (Smith, 1986; Weintraub, 1999, 2001; Prijono et al., 2004; Saito, 2004; Tokumaru, 2004; Tokumaru et al., 2005). Generally, growers apply insecticide early after a few mines on several leaves are seen, and multiple applications are usually made. To determine an appropriate timing of insecticide applications, chemical residues left in treated plants should be considered. Weintraub (2001) reported that the cyromazine residues left in potatoes from a single application were sufficient to control larval population of the pea leafminer $L$. huidobrensis until 42 days after treatment. Thus, single application of cyromazine could be effective in suppressing on L chinensis population in the fields.

Formulation of cartap, permethrin and phenthoate are labeled for citrus leafminer management, and are commonly used for management of leafminers on vegetable crops in Vietnam (Tran and Takagi, 2005). Tran and Takagi (2005) reported that these insecticides were highly or moderately effective on either larvae or adults of $L$. chinensis in the laboratory. Conversely, the field evaluation indicated that these insecticides with field recommended doses were less effective on larvae of the leafminer in the fields (Table 2). The number of adult $L$. chinensis captured was not significantly different among the treatments (Table 3). Since the efficacy of traps may vary depending on trap density and wind velocity (Chavez and Raman, 1987), our result could have been influenced by the experimental design with small plots and high trap density.

In Hue City, onion growers apply too-frequent, high concentration, and unnecessary use of insecticides. The widespread and intensive use of insecticides had led to development of resistance of Liriomyza leafminers to most of the chemicals registered for control (Parrella, 1983; Parrella and Keil, 1984; Sanderson et al., 1989; Keil and Parrella, 1990; Ferguson, 2004), with some insecticides retaining their effectiveness for only two years after introduction (Ferguson, 2004). Previous studies indicated the development of resistance in $\mathrm{L}$. trifolii to several insecticides such as permethrin (Parrella, 1983; Mason et al., 1987; Sanderson et al., 1989; Parrella and Trumble, 1989), spinosad (Ferguson, 2004). Mason et al. (1987) reported that resistance to pyrethroids (e.g. permethrin) also has been developed in L. sativae on Oahu, Hawaii. Resistance to cypermethrin and profenophos by L. sativae larvae has been indicated in populations from three different localities from Hanoi, Vietnam (Johasen et al., 2003). Resistance to insecticides of $L$. chinensis was not investigated in this study. As not effective of cartap, permethrin and phenthoate against $L$. chinensis was found in the field experiments, and Vietnamese growers have claimed control failure from these insecticides over last years, $L$. chinensis in Hue City seems to be resistant to these chemicals. The resistance to these insecticides should be investigated further, and the use of these insecticides against $L$. chinensis should be paused in this area until the resistance situation is clear. Because of different modes of action and no cross resistance between each other (e.g. cyromazine and abamectin (Leibee and Capinera, 1995)), some effective insecticides are available for rotation to manage the development of insecticide resistance within a Liriomyza population (Ferguson, 2004). The resistance should be concerned in chemical control of $L$. chinensis only when necessary with a rotation of effective materials (e.g. cyromazine, spinosad, phenthoate, dimethoate, emamectin benzoate, permethrin, and cartap) (Tran and Takagi, 2005).

The effectiveness of insecticides on leafminer management has been dogged by their indiscriminate use, impact on natural enemies and the development of resistance within fly population (Murphy and LaSalle, 1999). Saito et al. (1996) reported that application of non-selective insecticides (e.g. permethrin, etofenprox, methomyl and prothiofos) induced outbreak of $L$. trifolii on the gerbera because they were not effective on the leafminer, but were strongly harmful to parasitoids. The finding indicates that insecticides that are effective on leafminer but harmless to parasitoids should be used for suppressing $L$. chinensis population. Prijono et al. (2004) reported that cyromazine was relatively safe for Hemiptarsenus varicornis (Girault), Opius sp., Gronotoma micromorpha (Perkins), and Diglyphus isaea (Walker), the parasitoids of $L$. huidobrensis. Since these species are common parasitoids of leafmining agromyzid pests (Konishi, 2004; Tran et al., 2005), it would prove to incorporate cyromazine into an integrated pest management (IPM) program of the stone leak leafminer L. chinensis in Vietnam.

\section{ACKNOWLEDGEMENTS}

We express our thanks to our farmer cooperators for their assistance and collaboration during survey in their fields. We gratefully acknowledge the critical comments by Dr. Takatoshi Ueno, Institute of Biological Control, Faculty of Agriculture, Kyushu University, Japan, to an earlier version of this manuscript. This research was supported in part by a grant-in-aid from the Ministry of Education, Culture, Sports, Science and Technology of Japan (No. 15208007).

\section{REFERENCES}

Andersen, A., E. Nordhus., V. T. Thang., T. T. T. An., H. Q. Hung and T. Hofsvang 2002 Polyphagous Liriomyza species (Diptera: Agromyzidae) in vegetables in Vietnam. Trop. Agric. (Trinidad), 79: 241-246

Chaves, G. L. and K. V. Raman 1987 Evaluation of trapping and trap types to reduce damage to potatoes by the leafminer, Liriomyza huidobrensis (Diptera, Agromyzidae). Insect Sci. Appl., 8: 369-372

Chen, X. X., X. Y. Lang., Z. H. Xu., J. H. He and Y. Ma 2003 The occurrence of leafminers and their parasitoids on vegetables and weeds in Hangzhou area, Southeast China. BioControl, 48: $515-527$

Ferguson, J. S. 2004 Development and stability of insecticide resistance in the leafminer Liriomyza trifolii (Diptera: Agromyzidae) to cyromazine, abamectin, and spinosad. $J$. 
Econ. Entomol., 97: 112-119

Hwang, C. Y. and H. C. Moon 1995 Effect of temperature on the development and fecundity of Liriomyza chinensis (Diptera: Agromyzidae). Korean J. Appl. Entomol., 34: 65-69 (in Korean with English summary)

Johansen, N. S., M. T. Tao, T. K. O. Le and E. Nordhus 2003 Susceptibility of Liriomyza sativae (Diptera: Agromyzidae) larvae to some insecticides scheduled for their control in North Vietnam. Grønn kunnskap, 7: 157-165

Johnson, M. W., E. R. Oatman and J. A. Wyman 1980 Effects of insecticides on populations of the vegetable leafminer and associated parasites on summer pole tomatoes. J. Econ. Entomol., 73: 61-66

Keil, C. B. and M. P. Parrella 1990 Characterization of insecticide resistance in two colonies of Liriomyza trifolii (Diptera: Agromyzidae). J. Econ. Entomol., 83: 18-26

Keil, C. B., M. P. Parrella and J. G. Morse 1985 Method for monitoring and establishing baseline data for resistance to permethrin by Liriomyza trifolii (Burgess). J. Econ. Entomol., 78: 419-422.

Konishi, K. 2004 An illustrated to the species of hymenopterous parasitoids of leafmining agromyzid pests. In "Proceedings of 2004 Asian science seminar on biological control of agricultural pests in Asia - Theory and Practice". JASS' 04, Fukuoka, Japan, pp: 40-56

Leibee, G. L. and J. L. Capinera 1995 Pesticide resistance in Florida insects limits management options. Fla. Entomol., 78: $386-399$

Mason, G. A., W. J. Marshall and B. E. Tabashnik 1987 Susceptibility of Liriomyza sativae and L. trifolii (Diptera: Agromyzidae) to permethrin and fenvalerate. J. Econ. Entomol., 80: 1262-1266

Murphy, S. T. and J. LaSalle 1999 Balancing biological control strategies in the IPM of New World invasive Liriomyza leafminers in field vegetable crops. Biocontrol News and Information, 20: 91-104

Oatman, E. R. and G. G. Kennedy 1976 Methomyl induced outbreak of Liriomyza sativae on tomato. J. Econ. Entomol., 69: 667-668

Parrella, M. P. 1983 Evaluations of selected insecticides for control of permethrin- resistant Liriomyza trifolii (Diptera: Agromyzidae) on Chrysanthemum. J. Econ. Entomol, 76 : 1460-1464

Parrella, M. P. and J. T. Trumble 1989 Decline of resistance in Liriomyza trifolii (Diptera: Agromyzidae) in the absence of insecticide selection pressure. J. Econ. Entomol, 8 : 365-368

Parrella, M. P., and C. B. Keil 1984 Insect pest management: the lesson of Liriomyza. Bull. Entomol. Soc. Am., 30: 22-25

Prijono, D., M. Robinson, A. Rauf, T. Bjorksten and A. A. Hoffmann 2004 Toxicity of chemicals commonly used in Indonesian vegetable crops to Liriomyza huidobrensis population and the Indonesian parasitoids Hemiptarsenus varicornis,
Opius sp., and Gronotoma micromorpha, as well as the Australian parasitoids Hemiptarsenus varicornis and Diglyphus isaea. J. Econ. Entomol., 97: 1191-1197

SAS Institute 1998 StatView 5.O.J. SAS Institute Inc.

Saito, T. 2004 Insecticide susceptibility of leafminer, Chromatomyia horticola (Goureau) (Diptera: Agromyzidae). Appl. Entomol. Zool., 39: 203-208

Saito, T., F. Ikeda and A. Ozama 1996 Effect of pesticides on parasitoid complex of serpentine leafminer Liriomyza trifolii (Burgess) in Shizuoka Prefecture. Jpn. J. Appl. Entomol. Zool. 40: 127-133 (in Japanese with English summary)

Sanderson, J. P., M. P. Parrella, and J. T. Trumble 1989 Monitoring insecticide resistance in Liriomyza trifolii (Diptera: Agromyzidae) with yellow sticky cards. J. Econ. Entomol., 82: 1011-1018

Shiao S. F. 2004 Morphological diagnosis of six Liriomyza species (Diptera: Agromyzidae) of quarantine importance in Taiwan. Appl. Entomol. Zool., 39: 27-39

Smith, R. F. 1986 Efficacy of selective insecticides against Liriomyza trifolii (Burgess) (Diptera: Agromyzidae), a leafminer of chrysanthemum. Can. Ent., 118: 761-766

Spencer, K. A. 1973 Agromyzidae (Diptera) of economic importance. Dr. W. Junk B.V., Publishers, The Hague.

Spencer, K. A. 1990 Host specialization in the world Agromyzidae (Diptera). Series Entomologica. Kluwer Acad. Pub., Dordrecht

Thang, V. T. 1999 Surveys of leafminers (Liriomyza) and their parasitoids on vegetable in Vietnam 1998. In "Proceedings of a Workshop on Leafminers of Vegetables in Southeast Asia", ed. By G. S. Lim, S. S. Soetikno and W. H. Loke, Serdang, Malaysia, CAB International, Southeast Asia Regional Centre, pp. 36-41.

Tokumaru, S. 2004 Occurrence and insecticide susceptibility of the vegetable leafminer Liriomyza sativae in Kyoto Prefecture. Jpn. Agri. Tech., 48: 22-27 (in Japanese)

Tokumaru, S., H. Kurita, M. Fukui and Y. Abe 2005 Insecticide susceptibility of Liriomyza sativae, $L$. trifolii, and $L$. bryoniae (Diptera: Agromyzidae). Jpn. J. Entomol. Zool., 49: 1-10 (in Japanese with English summary)

Tran, D. H. and M. Takagi 2005 Susceptibility of the stone leek leafminer Liriomyza chinensis (Diptera: Agromyzidae) to insecticides. J. Fac. Agr., Kyushu Univ., 50: 383-390

Tran, D. H., T. T. A. Tran and M. Takagi 2005 Agromyzid leafminers in central and southern Vietnam: Surveys of host crops, species composition and parasitoids. Bull. Inst. Trop. Agr., Kyushu Univ., 28: 35-41

Weintraub, P. G. 1999 Effects of cyromazine and abamectin on the leafminer, Liriomyza huidobrensis and its parasitoid, Diglyphus isaea in celery. Ann. Appl. Biol., 135: 547-554

Weintraub, P. G. 2001 Effects of cyromazine and abamectin on the leafminer, Liriomyza huidobrensis and its parasitoid, Diglyphus isaea (Hymenoptera: Eulophidae) in potatoes. Crop Prot., 20: 207-213 